\title{
UJI KUALITATIF KANDUNGAN HARA KOMPOS CAMPURAN BEBERAPA KOTORAN TERNAK PELIHARAAN
}

\section{QUALITATIVE TEST CONTENT OF THE COMPOST MIX SOME DIRT DOMESTICATED CATTLE}

\author{
Meity Tumimbang1), Zetly E. Tamod2), dan Wiesje Kumolontang2) \\ 1)Mahasiswa Agroekoteknologi Minat Sumberdaya Lahan \\ 2)Staf Pengajar Ilmu Tanah Fakultas Pertanian Unsrat Manado, 95115
}

\begin{abstract}
The purpose of this research is to find out the nutrient content on five types of livestock manure compost which made of the mix of some livestock manure. This research uses three stages starting from the inventory, then analyzing the data, and finally interpretation of the data for the parameters: follow-up material, color, odor, moisture or water content, Reaction Fertilizer PH, Levels of C Organic, Levels of Total $\mathrm{N}$, Total $\mathrm{P}$, Total $\mathrm{K}$, and Fe. The inventory stage is conducted in laboratory using fast accurate qualitative methods based on Soil Research Center manual guide (2015). The research showed the results of the analysis of physical quality of blackish brown color, soil smells, moisture content less than $50 \%$ have met the Indonesian National Standard (SNI) 19-7030-2004. However, based on Decree of the Minister of Agriculture no 28/Permentan/SR.130/B/2009, the water content obtained under the requirements is only in the range of 7.82 to 13.31 from $15-25 \%$ while the follow-up material showed $<2 \%$. The test results using a set of compost test tools showed $N$ Total content of the livestock manure mixture compost that were made in the range of 2-3\% (SNI standard $>0,4 \%$ and Decree of the Minister of Agriculture $<6 \%$ ), P2O5 1-1.5\% (SNI standard $>0.1 \%$ and Decree of the Minister of Agriculture $<6 \%$ ), C-Organic 10\% (SNI standard $>9,8-32 \%$ and Decree of the Minister of Agriculture $>12 \%$ ), and $\mathrm{Fe}$ content 1000-2000 ppm (Decree of the Minister of Agriculture standard 0-8000 ppm), PH 5-7 (SNI standard 6,8 and Decree of the Minister of Agriculture standard 7,49).
\end{abstract}

Key words: compost, domesticated cattle

\begin{abstract}
ABSTRAK
Tujuan penelitian ini untuk mengetahui kandungan hara kompos pada 5 jenis kompos campuran beberapa kotoran ternak peliharaan. Penelitian ini menggunakan tiga tahap dimulai dari inventarisasi, kemudian analisis data dan selanjutnya interpretasi data untuk parameter: bahan ikutan, warna, bau, kadar air, Reaksi Pupuk pH, Kadar C Organik, Kadar N-Total, P Total, K Total, Fe. Tahap inventarisasi dilakukan di laboratorium menggunakan metode kualitatif selidik cepat berdasarkan panduan Balai Penelitian Tanah (2015). Hasil penelitian menunjukkan hasil analisis kualitas fisik warna coklat kehitaman, berbau tanah pada, kadar air kurang dari 50\% telah memenuhi SNI 19-7030-2004. Namun berdasarkan SK Mentan No 28/Permentan/SR.130/B/2009, kadar air yang diperoleh di bawah persyaratan hanya pada kisaran 7,82-13,31 dari persyaratan 15-25\% sedangkan bahan ikutan menunjukkan $<2 \%$. Hasil uji dengan menggunakan seperangkat alat uji kompos menunjukkan kandungan $\mathrm{N}$ total untuk kompos campuran kotoran ternak yang dibuat berada pada kisaran 2-3\% (standar SNI >0,4\% dan SK Mentan <6\%), $\mathrm{P}_{2} \mathrm{O}_{5} 1-1.5 \%$ (standar SNI $>0,1 \%$ dan SK Mentan $<6 \%$ ), $\mathrm{K}_{2} \mathrm{O}<1 \%$ (standar SNI $>0,2 \%$ dan SK Mentan $<6 \%$ ), C-organik 10\% (standar SNI $>9,8-32 \%$ dan SK Mentan >12\%),dankadar Fe 1000-2000 ppm (standar SK Mentan 0-8000 ppm), pH 5-7 (standar SNI 6,8 dan SK Mentan 7,49).

Kata kunci : kompos, kotoran ternak peliharaan
\end{abstract}

Eugenia Volume 22 No. 3 Oktober 2016 


\section{PENDAHULUAN}

Pertanian berkelanjutan bisa diwujudkan melalui berbagai macam sistem usaha tani, termasuk pertanian organik yang menekankan daur ulang hara secara alami, sehingga penggunaan input luar pertanian menjadi rendah. Penerapan pertanian organik sangat menekankan pada pengetahuan lokal petani, mulai dari pengelolaan tanah, pemilihan bibit lokal, sampai panen. Semua sistem yang digunakan saling terintegrasi satu sama lain, namun tetap berprinsip sama, yaitu melarang penggunaan input luar tinggi yang bersifat kimiawi.

Keberhasilan produksi pertanian dalam kegiatan intensifikasi akan ditentukan oleh sarana produksi yakni pupuk. Jika hara yang tersedia dalam tanah tidak mampu mencukupi kebutuhan tanaman maka semakin lama akan terjadi kemiskinan hara pada tanah tersebut, sehingga tanah berkurang kesuburannya (Sri Nuryani, dkk., 2010). Lebih lanjut dinyatakan bahwa pada pemberian pupuk makro berkadar tinggi dengan tanaman jenis unggul menaikan produksi tanaman, tetapi ekstraksi dan pengangkutan unsur hara mikro dari dalam tanah juga semakin meningkat. Menurut Soegiman (1982), adanya pemberian pupuk makro kurang ikutan unsur hara mikro, ikut mempertajam menurunnya unsur hara dari dalam tanah.

Salah satu usaha untuk meningkatkan efisiensi pemupukan adalah pemberian bahan organik, berupa bahan organik langsung berupa kompos atau pupuk kandang ataupun hasil ekstraksi bahan organik seperti asam humatffulfat (Sri Nuryani, dkk., 2010). Permasalahan sekarang, pupuk organik yang dikomposkan dan digunakan di lahan pertanian perlu pemenuhan standar mutu yang dapat diterima. Apalagi pupuk organik kompos yang beredar di pasaran komposisi jenisnya bervariasi dan pengujian kualitasnya sebagian belum dibuktikan. Salah satu upaya perlindungan petani, dengan melakukan uji kualitas pupuk organik di laboratorium. Hal ini, guna menjamin mutu sesuai dengan SNI (2004) dan sesuai persyaratan teknis minimal yang ditetapkan oleh Kementerian Pertanian Tahun (2009). Menjawab permasalahan tersebut, melalui penelitian ini bertujuan untuk mengetahui kandungan hara kompos pada 5 jenis kompos campuran beberapa kotoran ternak peliharaan.

\section{METODE PENELITIAN}

Penelitian mulai dilaksanakan pada Bulan Mei 2016 sampai dengan Bulan Juli 2016. Lokasi penelitian dilaksanakan di Lokasi UPT Kompos Fakultas Pertanian, Sub Laboratorium Bioteknologi Tanah, Sub Laboratorium Kimia dan Kesuburan Tanah pada Jurusan Tanah Fakultas Pertanian Universitas Sam Ratulangi Manado.

Bahan utama yang digunakan dalam penelitian ini adalah pupuk kompos campuran seresah daun dan kotoran ternak hasil produksi UPT Kompos Fakultas Pertanian Unsrat. Kotoran ternak peliharaan yang dimaksud merupakan bahan campuran yang diberikan pada saat proses pengomposan yakni bersumber: (1) kotoran sapi, (2) kotoran kuda, (3) kotoran babi, (4) kotoran kambing dan (5) kotoran kelinci seperti yang ditunjukkan pada Gambar 1.

Penelitian ini menggunakan tiga tahap penelitian yaitu inventarisasi, analisis data dan interpretasi data untuk parameter:bahan ikutan, warna, bau, kadar air, Reaksi Pupuk pH, Kadar C Organik, Kadar N-Total, P Total, K Total, Fe.

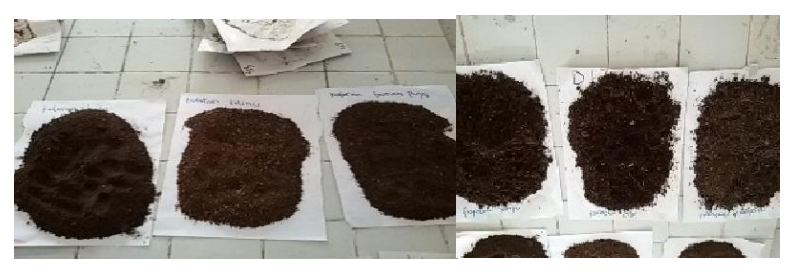

Gambar 1. Sampel Kompos Campuran Beberapa Kotoran Ternak Peliharaan

(Figure 1. Sample of the Mix Compost Some Domesticated Cattle) 
Uji ini dilakukan di laboratorium menggunakan metode kualitatif selidik cepat berdasarkan panduan Balai Penelitian Tanah (2015) antara lain:

\section{Cara Penetapan Kadar Bahan Organik}

Contoh pupuk diambil sebanyak satu sendok takar kecil (sekitar 0,5), Contoh dimasukkan ke dalam tabung reaksi, ditambahkan $5 \mathrm{ml}$ pereaksi C1, lalu dikocok, diamkan selama 5 menit (setiap 1 menit dihomogenkan dengan mengocok selama 10 menit). Kemudian ditambahkan $1 \mathrm{ml}$ pereaksi C2. Kocok hingga pereaksi bercampur dan homogen. Biarkan selama 10 menit. Pindahkan sebanyak $1 \mathrm{ml}$ ekstrak jernih (cairan bagian atas) ke dalam tabung lain. Tambahkan air bebas ion sebanyak $1 \mathrm{ml}$. Kocok hingga homogen (warna merata). Amati warna pada menit ke 15 kemudian bandingkan dengan bagan warna $\mathrm{C}$.

\section{Cara Penetapan pH}

Dimasukkan $0,5 \mathrm{~g}$ contoh ke dalam gulungan kertas saring. Gulungan berisi contoh dimasukkan ke dalam tabung. Tambahkan pengekstrak pH1 hingga $5 \mathrm{ml}$, biarkan 1 menit. Goyangkan tabung beberapa kali hingga 2 menit. Teteskan 1 tetes pereaksi pH2. Goyangkan kembali tabung perlahan sehingga larutan homogen. Amati warna larutan (maksimum hingga 15 menit).

\section{Cara Penetapan Kadar Hara Nitrogen (N)}

Contoh pupuk halus diambil sebanyak satu sendok takar kecil (0,5 gram). Contoh dimaukkan ke dalam tabung reaksi, ditambahkan $5 \mathrm{ml}$ pereaksi $\mathrm{N} 1$, lalu dikocok \pm 10 detik (hingga homogen), didiamkan 5 menit dan disaring. Pindahkan sebanyak $1 \mathrm{ml}$ filtrat (ekstrak jernih) ke dalam tabung reaksi lalu ditambah $1 \mathrm{ml}$ pereaksi N2, dikocok dan didiamkan selama 5 menit. Pindahkan $1 \mathrm{ml}$ ekstrak ke dalam tabung reaksi, ditambahkan $1 \mathrm{ml}$ pereaksi $\mathrm{N} 3$, dikocok, ditambahkan beberapa butir N4, dikocok, diamkan 5 menit. Pindahkan $1 \mathrm{ml}$ ekstrak ke dalam abung reaksi, ditambahkan $1 \mathrm{ml}$ pereaksi N5, dikocok, ditambahkan $2 \mathrm{ml}$ pereaksi N6 dan kocok. Amati perubahan warna, bandingkan dengan bagan warna $\mathrm{N}$ pada menit ke 5 .

\section{Cara Penetapan Kadar Hara Fosfor (P)}

Contoh pupuk diambil sebanyak satu sendok takar kecil $(0,5 \mathrm{~g})$. Contoh dimasukkan ke dalam tabung reaksi, ditambahkan $10 \mathrm{ml}$ pereaksi P1, lalu dikocok hingga homogen ( \pm 10 detik). Biarkan 5 menit sambil sesekali dikocok, lalu disaring. Pindahkan $1 \mathrm{ml}$ ekstrak jernih ke dalam tabung lain. Tambahkan air bebas ion hingga volume ekstrak menjadi $10 \mathrm{ml}$. Kocok supaya homogen. Pindahkan $1 \mathrm{ml}$ ekstrak ke dalam tabung reaksi lain, tambahkan $1 \mathrm{ml}$ pereaksi P2 dan dikocok. Tambahkan beberapa butir pereaksi $\mathrm{P} 3$, kemudian dikocok sampai butiran larut. Amati perubahan warna larutan, bandingkan dengan bagan warna P pada menit ke 15 .

\section{Cara Penetapan Kadar Hara Kalium (K)}

Contoh pupuk diambil sebanyak satu sendok takar kecil $(0,5 \mathrm{~g})$. Contoh dimasukkan ke dalam tabung reaksi, ditambahkan $5 \mathrm{ml}$ pereaksi K1, lalu dikocok hingga homogen, didiamkan selama 15 menit dan disaring. Pindahkan $1 \mathrm{ml}$ ekstrak jernih ke dalam tabung reaksi, ditambahkan $1 \mathrm{ml}$ pereaksi K2, kocok hingga homogen. Ditambahkan 1-2 tetes pereaksi K3 perlahan-lahan melalui dinding tabung (jangan dikocok). Amati pembentukan endapan putih berbentuk kabut diatas larutan kuning pada menit ke 15.

\section{Cara Penetapan Kadar Besi (Fe)}

Contoh pupuk diambil sebanyak satu sendok takar kecil $(0,5 \mathrm{~g})$. Contoh dimasukkan ke dalam tabung reaksi, ditambahkan $5 \mathrm{ml}$ pereaksi Fe1, lalu dikocok, diamkan selama 5 menit sambil sesekali dikocok, kemudian disaring. Pindahkan $1 \mathrm{ml}$ ekstrak jernih ke dalam tabung lain, ditambahkan $1 \mathrm{ml}$ pereaksi Fe2, kocok dan diamkan 5 menit. Pindahkan $1 \mathrm{ml}$ larutan tadi ke tabung reaksi lain, ditambahkan $1 \mathrm{ml}$ pereaksi Fe3, kocok dan diamkan 5 menit. Ditambahkan $1 \mathrm{ml}$ pereaksi Fe4, kocok. Bandingkan warna larutan contoh dengan bagan warna Fe pada menit ke 5 .

Hasil penilaian selanjutnya dibandingkan dengan SNI 19-7030-2004 dan berdasarkan persyaratan teknis minimal organik SK Mentan nomor 28/Permentan/SR.130/B/2009. Hasil tahap analisis selanjutnya diinterpretasikan dalam bentuk uraian secara deskriptif tentang kandungan hara yang ada 
di kompos tersebut berdasarkan hasil selidik cepat. Uraian deskriptif akan dilengkapi dengan beberapa tabel dan gambar yang mendukung.

\section{HASIL DAN PEMBAHASAN}

Contoh pupuk organik diaduk hingga homogen dan diayak dengan ayakan $2 \mathrm{~mm}$. Bahan yang tidak lolos ayakan merupakan bahan ikutan (plasik, kaca, kerikir dan lain-lain) dipisahkan dan ditimbang. Semua analisis mengunakan contoh pupuk yang lolos ayakan $2 \mathrm{~mm}$ (contoh halus) kecuali kadar air contoh asal dan kadar bahan ikutan. Hasil uji fisik di laboratorium untuk lima jenis kompos campuran kotoron ternak, disajikan pada Tabel 1.

Hasil analisis kualitas fisik menunjukkan kualitas fisik warna coklat - kehitaman, berbau tanah pada suhu ruang normal, kadar air kurang dari $50 \%$ telah memenuhi SNI 19-7030-2004. Namun berdasarkan SK Mentan No 28/Permentan/SR.130/ $\mathrm{B} / 2009$, kadar air yang diperoleh di bawah persyaratan hanya pada kisaran 7,82 - 13,31 dari persyaratan $15-25 \%$ sedangkan bahan ikutan menunjukkan $<2 \%$. Untuk uji kandungan hara NPK, Corganik, Fe dan reaksi kompos telah dilakukan seperti yang ditunjukkan pada Gambar 2 dan hasilnya pada Tabel 2.

Hasil uji dengan menggunakan seperangkat alat uji kompos menunjukkan kandungan $\mathrm{N}$ total untuk kompos campuran kotoran ternak kelinci, kambing, kuda, sapi, babi, berada pada kisaran 2$3 \%$ (standar SNI $>0,4 \%$ dan SK Mentan $<6 \%$ ), $\mathrm{P}_{2} \mathrm{O}_{5}$ $1-1.5 \%$ (standar SNI >0,1\% dan SK Mentan $<6 \%$ ), $\mathrm{K}_{2} \mathrm{O}<1 \%$ (standar $\mathrm{SNI}>0,2 \%$ dan SK Mentan $<6 \%$ ), C-organik $10 \%$ (standar SNI $>9,8-32 \%$ dan SK Mentan $>12 \%$ ), dan kadar Fe 1000-2000 ppm (standar SK Mentan 0-8000 ppm), pH 5-7 (standar SNI 6,8 dan SK Mentan 7,49).

Tabel 1. Sifat Fisik Warna, Bau, Kadar Air dan Bahan Ikutan Kompos Campuran Kotoran Ternak

(Table 1. Physical Character, Color, Odor, Moisture and Compost Mix of Cattle)

\begin{tabular}{|c|c|c|c|c|c|c|}
\hline No. & $\begin{array}{c}\text { Jenis Kompos } \\
\text { Campuran } \\
\text { Kotoran Ternak }\end{array}$ & Warna & Bau & $\begin{array}{l}\text { Kadar Air } \\
(\%)\end{array}$ & $\begin{array}{c}\text { Bahan } \\
\text { Ikutan } \\
(\%) \\
\end{array}$ & Hasil \\
\hline 1. & Kelinci & Coklat Kehitaman & Berbau tanah & 7.82 & 1.77 & Sesuai \\
\hline 2. & Kambing & Coklat Gelap & Berbau tanah & 10.98 & 1.36 & Sesuai \\
\hline 3. & Kuda & $\begin{array}{l}\text { Coklat ke abu-abuan } \\
\text { sangat gelap }\end{array}$ & Berbau tanah & 11.88 & 1.97 & Sesuai \\
\hline 4. & Sapi & Coklat sangat gelap & Berbau tanah & 11.20 & 1.80 & Sesuai \\
\hline 5. & Babi & Coklat Kehitaman & Berbau tanah & 9.58 & 1.87 & Sesuai \\
\hline Standa & SNI 2004 & Kehitaman & Berbau tanah & $<50$ & & \\
\hline \multicolumn{2}{|c|}{ SK Mentan 2009} & & & $15-25$ & $<2$ & \\
\hline
\end{tabular}

Sumber : Hasil Analisis Laboratorium

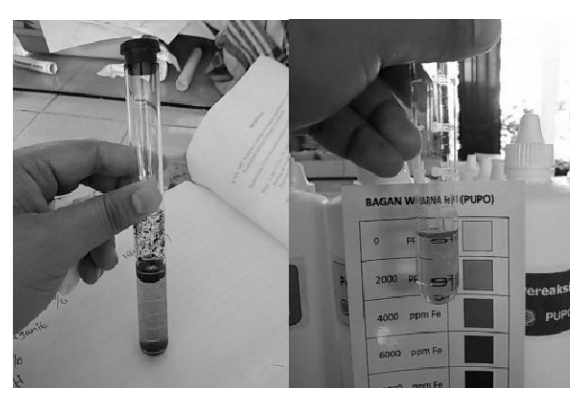

Gambar 2. Pemeriksaan Uji Kualitatif Kompos di Laboratorium

(Figure 2. Examination Compost Qualitative Test in the Laboratory) 
Tabel 2. Kandungan Hara N, P, K, C-Organik, Fe, Kompos Campuran Kotoran Ternak (Metode Seperangkat Uji Kompos) Uji Kualitatif)

(Table 2. The Content of Nutritient N, P,K, C-Organic, Fe, Mixed Livestock Manure Compost (Using a Set of Compost Test Tools) Qualitative Test)

\begin{tabular}{|c|c|c|c|c|c|c|c|c|}
\hline No & $\begin{array}{c}\text { Jenis Kompos } \\
\text { Campuran } \\
\text { Kotoran } \\
\text { Ternak }\end{array}$ & $\begin{array}{c}N \text { total } \\
(\%)\end{array}$ & $\begin{array}{l}\mathrm{P}_{2} \mathrm{O}_{5} \\
(\%)\end{array}$ & $\begin{array}{l}\mathrm{K}_{2} \mathrm{O} \\
(\%)\end{array}$ & $\begin{array}{c}\text { C Organik } \\
(\%)\end{array}$ & $\begin{array}{c}\mathrm{Fe} \\
(\mathrm{ppm})\end{array}$ & $\mathrm{pH}$ & Hasil \\
\hline 1. & Kelinci & 2 & 1,5 & $<1$ & 10 & 1000 & 5 & $\begin{array}{l}\text { Sesuai SNI \& } \\
\text { SK Mentan }\end{array}$ \\
\hline 2. & Kambing & 2 & 1,5 & $<1$ & 10 & 1000 & 7 & $\begin{array}{l}\text { Sesuai SNI \& } \\
\text { SK Mentan }\end{array}$ \\
\hline 3. & Kuda & 2 & 1 & $<1$ & 10 & 1000 & 5 & $\begin{array}{l}\text { Sesuai SNI \& } \\
\text { SK Mentan }\end{array}$ \\
\hline 4. & Sapi & 2 & 1 & $<1$ & 10 & 1000 & 6,5 & $\begin{array}{l}\text { Sesuai SNI \& } \\
\text { SK Mentan }\end{array}$ \\
\hline 5. & Babi & 3 & 1 & $<1$ & 10 & 2000 & 6 & $\begin{array}{l}\text { Sesuai SNI \& } \\
\text { SK Mentan }\end{array}$ \\
\hline Stanc & $\operatorname{lar}$ SNI 2004 & $>0,40$ & $>0,10$ & $>0,20$ & $>9,8-32$ & & $6,8-7,49$ & \\
\hline SKM & entan 2009 & $<6$ & $<6$ & $<6$ & $>12$ & $0-8000$ & $4-8$ & \\
\hline
\end{tabular}

Hasil uji kualitas fisik dan kimia kompos yang telah dilakukan di laboratorium berdasarkan beberapa parameter, rata-rata memenuhi beberapa standar kompos berdasar SNI 19-7030-2004 dan SK Mentan No 28/Permentan/SR.130/B/2009. Kualitas fisik dan kimia masing-masing kompos yang telah diuji memiliki kandungan hara yang bervariasi untuk tiap jenis kompos yang berasal dari beberapa jenis kotoran hewan. Perbedaan kandungan hara kemungkinan disebabkan dari jenis makanan yang dikonsumsi oleh ternak sehingga kotoran yang dihasilkan bervariasi kandungan hara. Fakta hasil uji jenis kompos tersebut mempunyai kandungan hara yang tersedia cukup baik dan kemungkinan kombinasi bahan baku dasar kompos sudah diolah secara optimal.

Untuk Nilai pH menunjukkan konsentrasi ion $\mathrm{H}^{+}$dalam larutan, yang dinyatakan sebagai -log $\left[\mathrm{H}^{+}\right]$. Peningkatan konsentrasi $\mathrm{H}^{+}$menaikkan potensial larutan yang di ukur oleh alat dan dikonversi dalam skala $\mathrm{pH}$. Elektroda gelas merupakan elektrode selektif khusus $\mathrm{H}^{+}$, hingga memungkinkan untuk hanya timbul diukur berdasarkan potensial elektrode pembanding (kalomel atas AgC1). Biasanya digunakan satu elektrode yang sudah terdiri atas elektrode pembanding dan elektrode gelas (elektroda kombinasi). Nilai $\mathrm{pH}$ kompos bersifat netral. Hasil penelitian menunjukkan nilai $\mathrm{pH}$ 6.637.02 telah memenuhi standar berdasar SNI 2004 yakni 4-8. Dalam kondisi normal, kompos tidak akan menimbulkan masalah, yang berarti dalam proses pengomposan dapat mempertahankan $\mathrm{pH}$ dalam kisaran netral (Utomo, 2010 dalam Tantri, $d k k ., 2016)$. pH netral aktivitas mikroorganisme dalam pupuk organik berjalan sempurna, sehingga unsur hara yang terlepas dari pupuk organik semakin baik.

Air dalam contoh pupuk organik diuapkan dengan cara pengeringan oven pada suhu $105^{\circ} \mathrm{C}$ selama semalam (16 jam). Hasil analisis kadar air menunjukkan 7.62-13.61 telah memenuhi standar SNI 2004. Apabila kadar air terlalu banyak, akan berakibat bahan semakin padat, karena dapat melumerkan sumber makanan yang dibutuhkan mikroba dan memblokir oksigen untuk masuk (Isroi dan Yuliarti, 2009). 


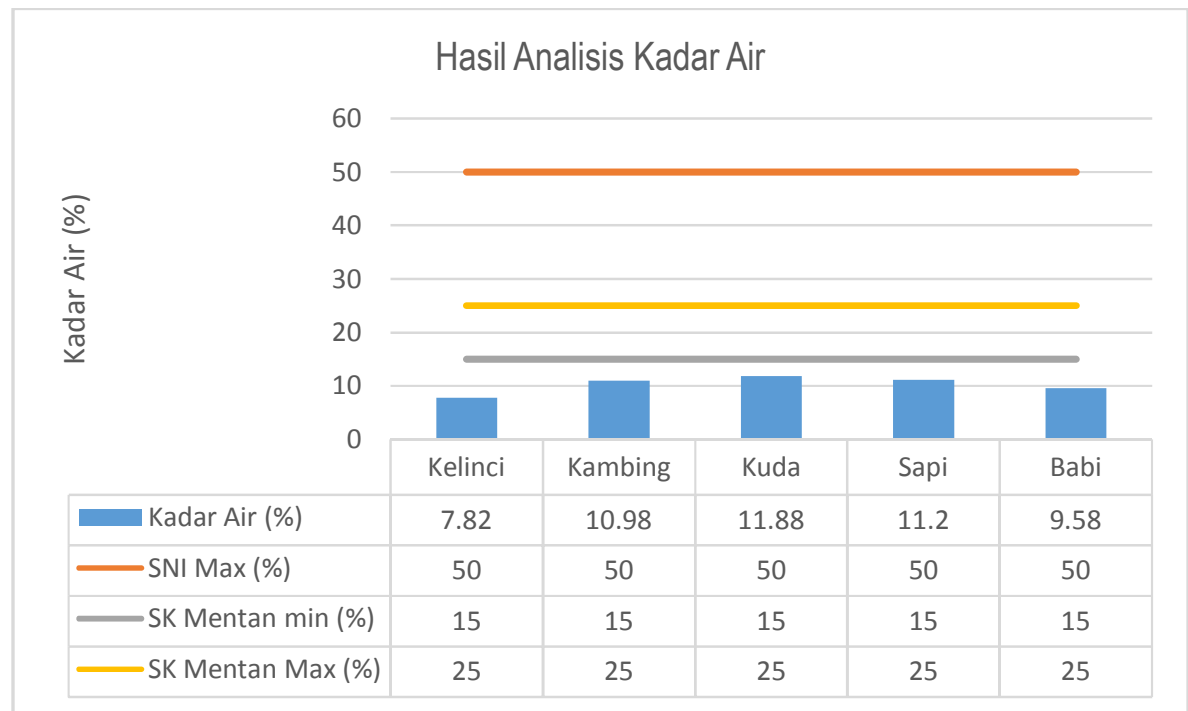

Gambar 3. Hasil Analisis Kadar Air

(Figure 3. The Results of the Analysis of Water Content)

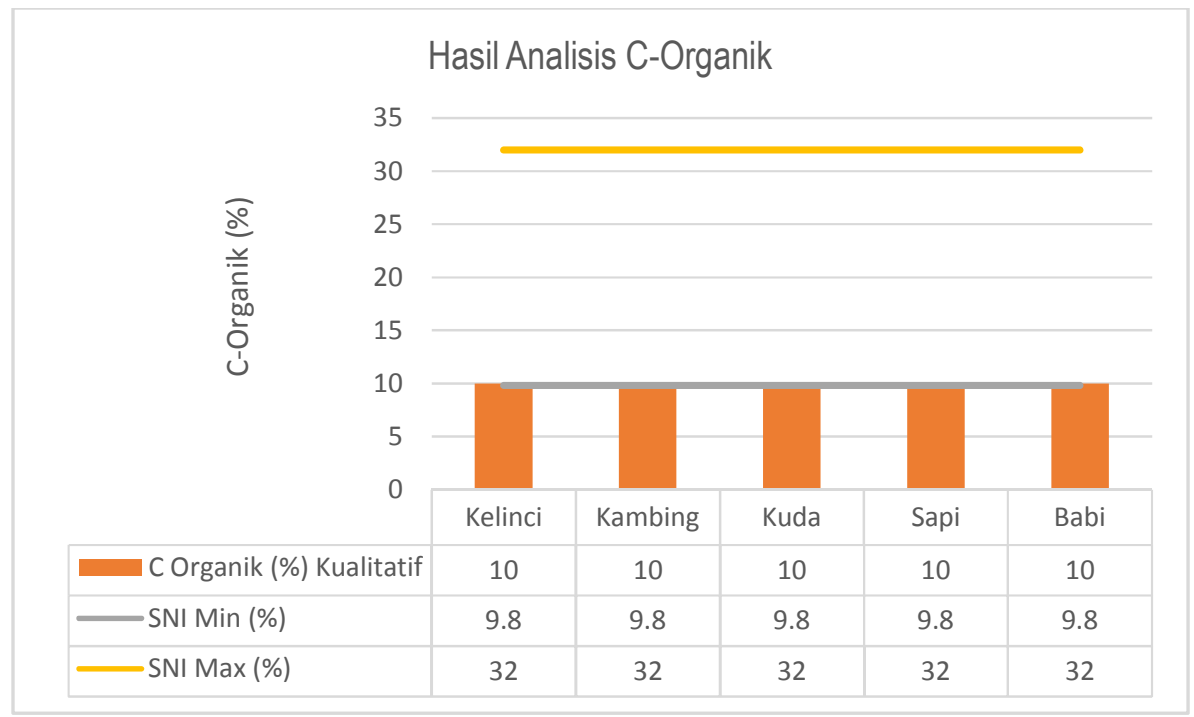

Gambar 4. Hasil Analisis C Organik

(Figure 4. The result of Analys C-Organic)

Hasil analisis kompos untuk kandungan Corganik menunjukkan telah memenuhi persyaratan SNI yaitu $10-15 \%$ untuk uji kualitatif dan 10.8413.71 untuk uji laboratorium. Total C-organik dipengaruhi oleh kualitas bahan organik dan aktivitas mikroorganisme yang terlibat dalam penguraian bahan organik. Kandungan bahan organik dari hasil kompos berada pada kisaran 18.69 - $23.63 \%$. Kandungan ini berada di bawah standar SNI 2004 yakni $27-58 \%$. Hal ini kemungkinan disebabkan oleh faktor dalam pembuatan kompos dan sumber serta cara pencampuran kompos. Kemungkinan lain cara pengambilan sampel untuk analisa juga mempengaruhi kandungan bahan organik.

Secara rinci kandungan hara yang diuji dapat dirinci berikut.

\section{Nitrogen (N)}

$\mathrm{N}$-organik dan $\mathrm{N}^{-\mathrm{NH}_{4}}$ yang terdapat dalam contoh didestruksi dengan asam sulfat dan sele- 
nium mixture membentuk amonium sulfat, didestilasi dengan penambahan basa berlebih dan akhirnya destilat dititrasi. Nitrogen dalam bentuk nitrat diekstraksi dengan air, direduksi dengan devarda alloy, didestilasi dan akhirnya dititrasi.

Kandungan nitrogen kompos yang diteliti bervariasi $2-3 \%$ berdasarkan uji secara kualitatif dan uji laboratotium pada nilai $0.67 \%-0.83 \%$. Berdasarkan hasil nilai kompos tersebut sudah memenuhi kandungan nitrogen berdasar SNI yaitu $>0,4 \%$. Hal ini ditunjang dengan bahan kompos yang digunakan diduga adanya kandungan mikroorganisme dalam kompos yang bersumber dari stater EM4 telah membantu proses pengomposan berlangsung. Tersedianya nitrogen dalam jumlah yang tinggi karena terjadi proses dekomposisi yang lebih sempurna, sedangkan nitrogen yang rendah disebabkan bahan baku kompos diduga mengandung nitrogen rendah dan kemungkinan terjadi penguapan (Golueke dalam Harada, 1990). Nitrogen yang ada memiliki sifat yang mudah hilang baik lewat penguapan maupun pencucian sehingga dalam pembuatan kompos perlu diperhatikan lingkungan pembuatan sehingga nitrogen yang ada tidak mudah hilang.

\section{Fospor $\left(\mathrm{P}_{2} \mathrm{O}_{5}\right)$}

Kandungan unsur hara phospor pada kisaran $1-1,5 \%$. Berdasarkan nilai kualitas $\mathrm{P}_{2} \mathrm{O}_{5}$ dari kompos yang dihasilkan telah memenuhi menurut SNI 19-7030-2004 yaitu >0,10\% untuk uji dengan menggunakan alat uji kompos secara kualitatif dan hasil uji laboratorium $0.22 \%-0.35 \%$. Unsur $P$ tersebut diperlukan oleh mikroorganisme untuk membangun sel (Stofella dan Khan, 2001). Adanya perombakan bahan organik dan proses asimilasi pospor terjadi karena adanya enzim fosfatase yang dihasilkan oleh sebagian mikroorganisme. Jika jumlah mikroorganisme dalam kompos kurang, maka proses perombakan bahan organik dan proses asimilasi fosfor oleh mikroorganisme akan kurang sehingga fosfor kurang termanfaatkan dan jika jumlah mikroorganisme dalam komposan cukup maka proses perombakan bahan organik berjalan sempurna.

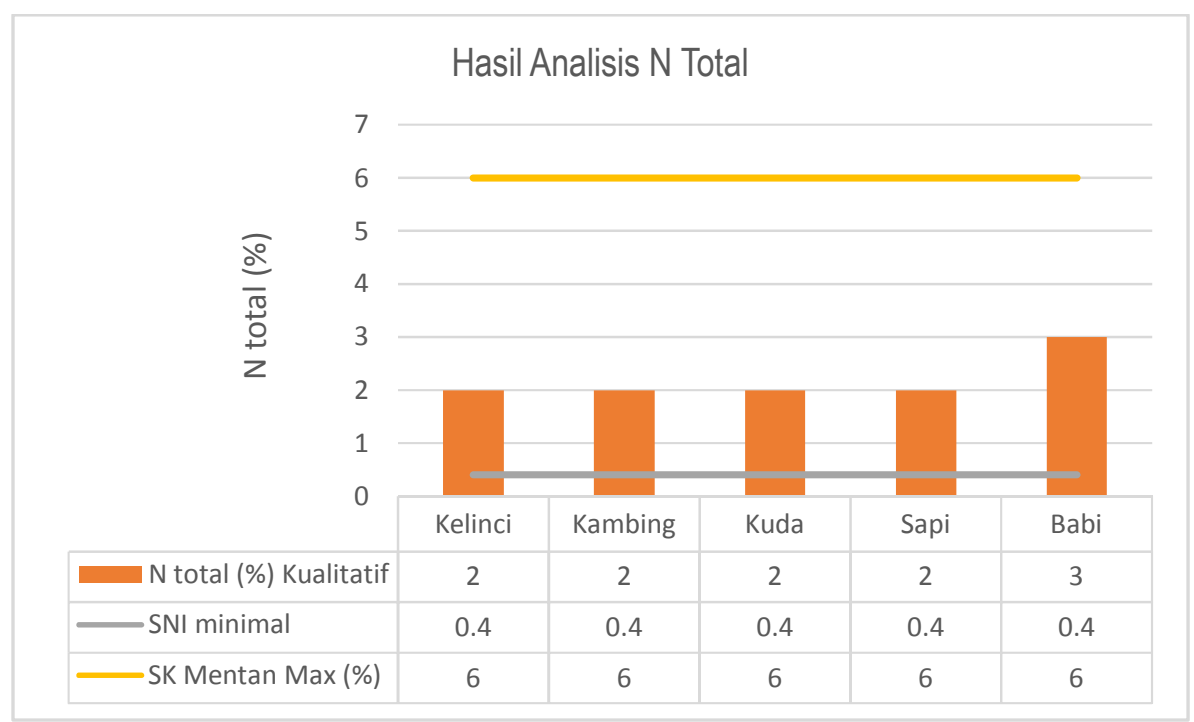

Gambar 4. Hasil Analisis Nitrogen Total

(Figure 4. The Result of Analys N Total) 


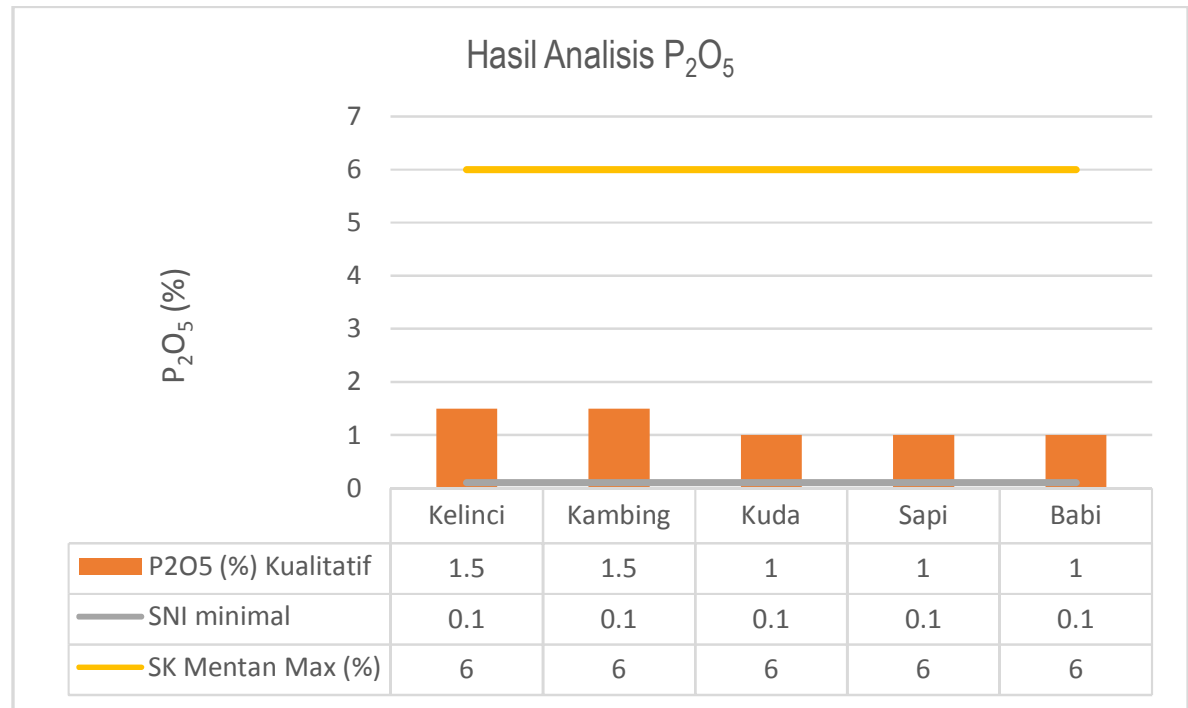

Gambar 5. Hasil Analisis Fospor $\left(\mathrm{P}_{2} \mathrm{O}_{5}\right)$

(Figure 5. The result of Fospor)

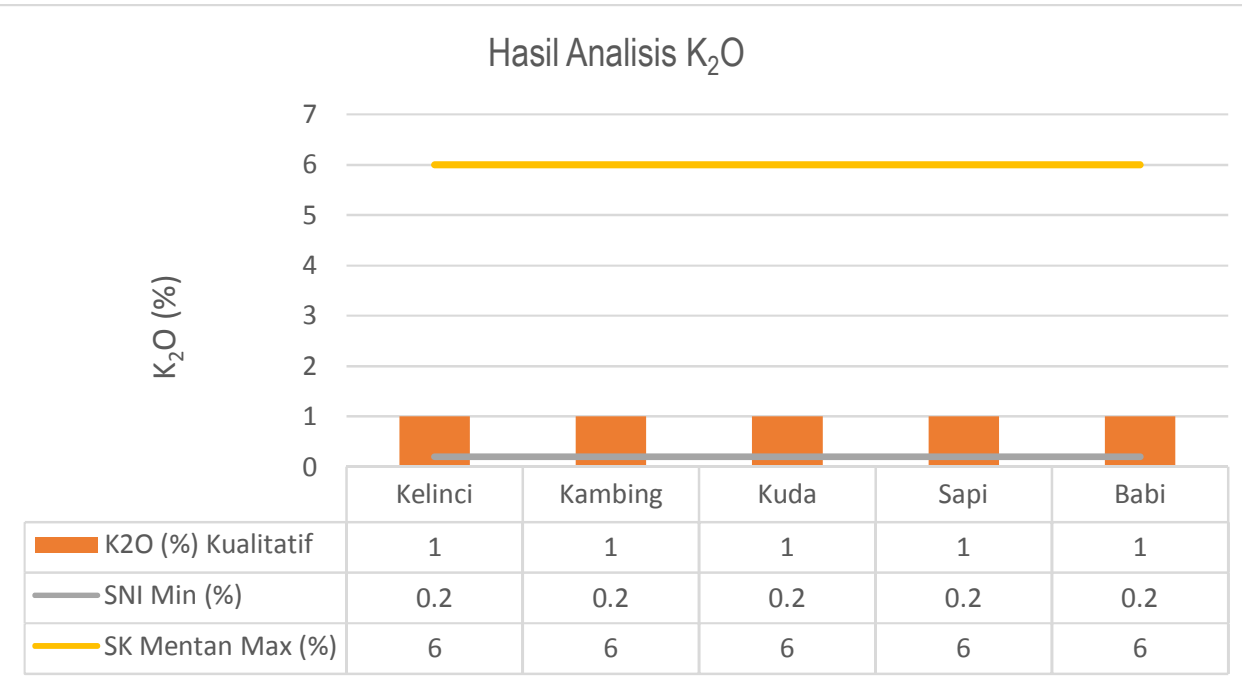

Gambar 6. Hasil Analisis Kalium $\left(\mathrm{K}_{2} \mathrm{O}\right)$

(Figure 6. The result of analys Calium)

\section{Kalium $\left(\mathrm{K}_{2} \mathrm{O}\right)$}

Hasil analisis kandungan kalium $<1 \%$ telah memenuhi standar SNI yaitu $>0,20 \%$ berdasarkan uji kualitatif dan uji laboratorium berada pada kisaran $0.23-0.28 \%$. Kalium digunakan oleh mikroorganisme dalam tahap komposan sebagai katalisator (Sutedjo, 1996). Kalium memiliki sifat yang demikian sangat mempengaruhi cepat lambatnya proses dekomposisi berlangsung. Kehadiran bakteri dengan aktivitasnya, berpengaruh terhadap peningkatan kandungan kalium. Kalium diikat dan disimpan dalam sel oleh bakteri dan jamur. Jika de- komposisi kembali maka kalium akan menjadi tersedia kembali.

\section{Besi (Fe)}

Hasil analisis kandungan Fe secara kualitatif menunjukkan nilai 1000-2000 ppm. Kandungan Fe yang tertinggi berada pada kompos campuran kotoran babi. Fe sangat berperan dalam penyusun enzim dan protein yang dibutuhkan oleh mikroorganisme serta dalam pernafasan dalam tubuh organisme. 


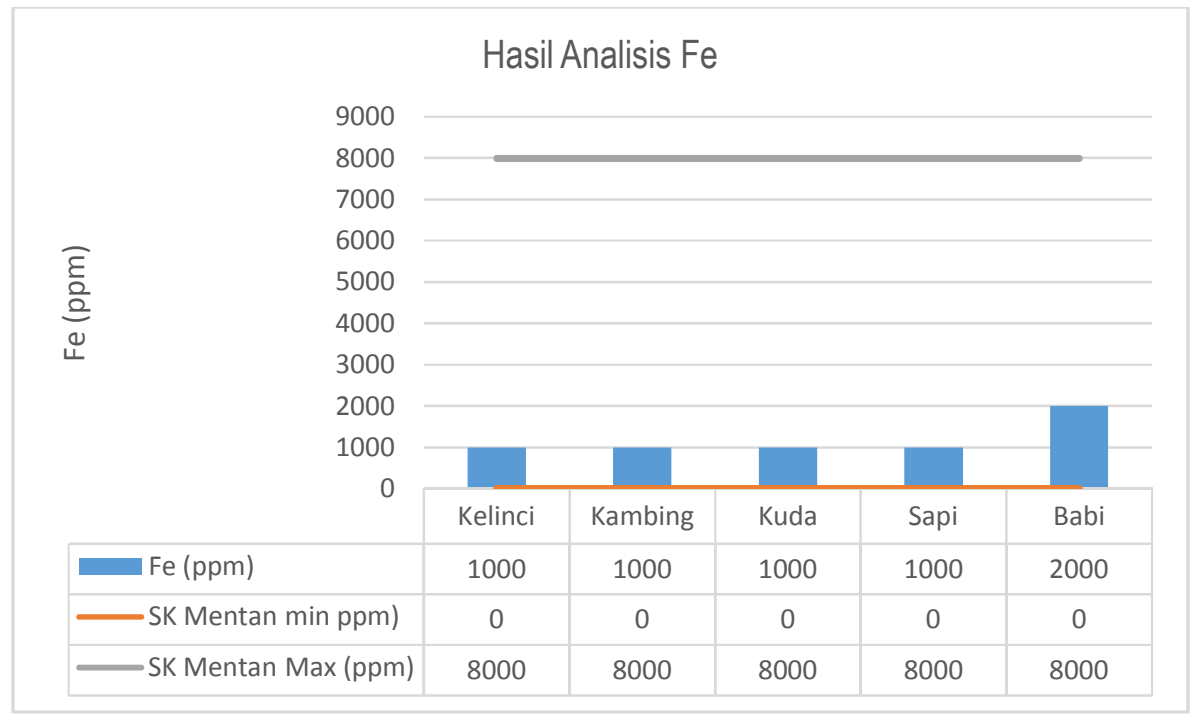

Gambar 7. Hasil Analisis Fe

(Figure 7. The Result of Analys Fe)

Status optimum hara dalam tanah tidak sama untuk semua tanaman pada suatu tanah. Hal yang sama status optimum untuk suatu tanaman berbeda untuk tanah yang berlainan. Oleh karena itu, untuk hara tanah yang telah berada dalam status optimum hanya diberikan seminimal mungkin kandungan unsur hara sebatas takaran perawatan untuk menggantikan yang terangkut panen. Penambahan hara yang tidak diperlukan justru menyebabkan masalah pencemaran lingkungan. Dengan diketahui status hara dalam tanah, maka dapat disusun rekomendasi pemupukan sesuai tingkat kesuburan tanah untuk mendukung pertumbuhan tanaman yang optimum. Salah satu rekomendasi yang diusulkan untuk keberlanjutan sistem pertanian yakni perlu dilakukan uji parameter kunci dari sifat-sifat tanah yang berpengaruh pada penyediaan unsur hara yang dapat menerangkan keragaman sifat tanah dalam satu ordo tanah yang sama. Hasil penelitian Widjaya-Adhi (1986) untuk membuat status hara tanah beragam diperlukan 3-5 bulan atau sekitar satu musim tanam. Diharapkan dalam waktu tersebut reaksi kimia antara hara pupuk dan hara tanah telah mencapai kondisi keseimbangan dalam larutan tanah atau dengan kata lain hara pupuk telah berubah menjadi hara tanah. Corey (1987) mengutip Glossary of soil science terms mendefinisikan hara tersedia adalah unsur hara dalam bentuk ion maupun senyawa yang dapat diserap dan digunakan untuk pertumbuhan tanaman. Fink (1982) menilai bentuk ikatan unsur hara seperti: bentuk ikatan tidak terikat dalam larutan akan sangat mudah ketersediaannya; bentuk ikatan lemah dalam kompleks jerapan akan mudah ketersediaannya; bentuk ikatan tidak bergerak (imobil), tetapi mudah dilepaskan ketersediaannya sedang; dan bentuk ikatan imobil dan sukar untuk dilepaskan ketersediaannya tidak tersedia.

Pemberian kompos yang bersumber dari bahan organik menurut Kumolontang dan Nangoy (2007) dan Setijono (1996) dapat meningkatkan ketersediaan $\mathrm{P}$ bagi tanaman. Lebih lanjut dinyatakan bahwa aplikasi di lahan pertanian, Bahan organik kompos dari sisa tanaman sebagai sumber pupuk $P$ harus mempunyai kandungan $P$ lebih dari $0,25 \%$ agar terjadi mineralisasi $\mathrm{P}$, bila kandungan $\mathrm{P}$ pada sisa tanaman kurang dari $0,25 \%$ akan terjadi mineralisasi $\mathrm{P}$ di dalam tubuh mikrobia dan tidak tersedia bagi tanaman (Neteeson dan Henrot, 1995). Adanya pemberian kompos sebagai sumber unsur hara untuk pertumbuhan tanaman, Tisdale dan Nelson, 1975 menilai nantinya tanaman akan respon secara signifikan terhadap pupuk (kompos) yang diberikan pada tanah yang kurang subur, pe- 
nelitian Ikgra (2002) menunjukkan pemberian 20 ton/ha pupuk kompos (lokasi jerami) dapat meningkatkan tinggi tanaman jagung berat kering tajuk dan berat kering tanaman jagung. Penelitian Rondonuwu (2010) menyatakan pemberian kompos organik berpengaruh sangat nyata terhadap tinggi tanaman jumlah daun, berat kering tanaman bagian atas tanah, dan berat kering akar tanaman jagung $40 \mathrm{HST}$.

\section{KESIMPULAN DAN SARAN}

\section{Kesimpulan}

Hasil penilaian terhadap parameter kompos menunjukkan kandungan hara $\mathrm{N}, \mathrm{P}, \mathrm{K}, \mathrm{C}$ organik, pH dan kadar air telah memenuhi SNI 2004 dan Permentan 2009. Kandungan $\mathrm{N}$ total untuk kompos campuran kotoran ternak kelinci, kambing, kuda, sapi, babi, yang dibuat berada pada kisaran 2-3\% (standar SNI >0,4\% dan SK Mentan $<6 \%$ ), $\mathrm{P}_{2} \mathrm{O}_{5} 1-1.5 \%$ (standar $\mathrm{SNI}>0,1 \%$ dan SK Mentan $<6 \%$ ), $\mathrm{K}_{2} \mathrm{O}<1 \%$ (standar $\mathrm{SNI}>0,2 \%$ dan SK Mentan $<6 \%$ ), C-organik 10\% (standar SNI $>9,8-32 \%$ dan SK Mentan >12\%), dan kadar Fe 1000-2000 ppm (standar SK Mentan 0-8000 ppm), pH 5-7 (standar SNI 6,8 dan SK Mentan 7,49).

\section{Saran}

Perlu dilakukan penelitian lanjut dengan indikator pertumbuhan dan produktivitas tanaman setelah diaplikasikan di lapangan

\section{DAFTAR PUSTAKA}

Corey, R.B. 1987. Soil Test Procedure. In J.R. Brown (Ed). Soil Testing: Sampling, Corelation, Calibration and Interpretation. Soil Science Society of America Special Publication No 21. SSSA, Madison Wisconsin.

Fink, A. 1982. Fertilizers and Fertilization: Introduction and Practical Guide to Crop Fertilization. Verlag Chemie. Weincheim. Federal Republic of Germany.
Harada,Y. 1990. Composting and Application of Animal Waste. ASPAC Food and Fertilizer Technology Center. Extension Bulletin No 311: 20-31.

Ikqra. 2000. Aplikasi Pupuk Bokasi pada Latosol Sea dengan Pertumbuhan Tanaman Jagung (Zea mays L.) sebagai Indikator.

Isroi dan N. Yuliarti. 2009. Kompos. Penerbit ANDI, Yogyakarta.

Kumolontang, W. J. dan R; Nangoi. Kompos yang Bersumber dari Bahan Organik. Soil Environment 5 (3) 22- 24.

Neteeson, J.J and J. Henrot. 1995. Summary.p 1-5. In Neeteson, J.J and Henrot (eds). The Role of plants Residues in soil Management for food Production in the Humid Tropic. Final report DGIS Project NG/91/852.

Rondonuwu, J. 2005. Laporan Penulisan Kesuburan Tanah. Staf Pengajar Jurusan Tanah Fakultas Pertanian Unsrat. Soil Environment 8 (2) : 54-59.

Setijono, S. 1996. Intisari Kesuburan Tanah. IKIP Malang Press. Malang.

SK Mentan No 28/Permentan/SR.130/B/2009, Pupuk Organik, Pupuk Hayati, Pembenah Tanah. Kementerian Pertanian Republik Indonesia.

SNI : 19-7030-2004. Spesifikasi Kompos dari Sampah Organik. Ciptakarya.pu.www. ciptakarya.co.id

Soegiman. 1982. Sifat dan Ciri Tanah. Terjemahan dari Buckman, H.O. dan N.C. Bardy. The Nature and Properties of Soil. Bhatara Karya Aksara. Jakarta. 
Sri Nuryani H.U., Muhsin Haji dan Nasih Widya Y. 2010. Serapan Hara N, P, K Pada Tanaman Padi dengan Berbagai Lama Penggunaan Pupuk Organik Pada Vertisol Sragen. Jurnal IImu Tanah dan Lingkungan Vol. 10 No 1 P: 1-13.

Stofella, P.J and Brian A. Khan. 2001. Compost Utilization in Holticultural Croping Systems. Lewis Publishers. USA.

Sutanto, Rachman. 2002. Penerapan Pertanian Organik, Pemasyarakatan dan Pengembangannya. Yogyakarta: Kanisius.

Sutedjo, M.M., A.G. Kartasapoetra dan Rd. S. Sastroatmodjo. 1996. Mikrobiologi Tanah. PT. Rhineka Cipta Pemupukan Cetakan ke-6, Penerbit PT Rineka Cipta, Jakarta.
Tantri, T.P.T.N., A.A.N. Supadma, I.D.M. Arthagama. 2016. Uji Kualitas beberapa Pupuk Kompos yang Beredar di Kota Denpasar. E.Jurnal-Agroekoteknologi Tropika 5 (1) 52-62. http//Ojs.Unud.ac.id.

Tisdale, S.J. and W.L. Nelson. 1975. Soil Fertility and Fertilizers. The Macmillan Co. New York.

Widjaja-Adhi, I.P.D and J.A. Silva. 1986. Calibration of Soil Phosphorus Test for Maize on Typic Paleudults and Trapeptic Eutrustox. Penerbit Penelitian Tanah dan Pupuk 6: 23-25 